\title{
Fenomena Manajemen Laba dalam IPO (Initial Public Offering); Studi dengan Menggunakan Model Aharony dan Friedlan
}

\author{
Lego Waspodo \\ Fakultas Ekonomi Universitas Lampung \\ Jl. Sumantri Brojonegoro No. 1 Bandar Lampung \\ Email: legowaspodo@yahoo.com
}

\begin{abstract}
The research was done on PT Multistrada Arah Sarana, during 2002 to 2007, using modifiedJones Model. The research used two means differentiation tests. Based on the result of two means differentiation test, it can be said that there was no income increasing discretionary accruals one year before initial public offering (on 2004). Issuers also did not do income-decreasing discretionary accruals on one year after initial public offering and two years after initial public offering.
\end{abstract}

Hipotesis 1 and hipotesis $2 \mathrm{a}$ and $2 \mathrm{~b}$ were refused, or can not be accepted. So, it can be concluded that PT Multisrada Arah Sarana did not do income smoothing before and after initial public offering on Indonesia Stock Exchange.

Keywords: income smoothing, income increasing discretionary accruals, income decreasing discretionary accruals, initial public offering.

\section{PENDAHULUAN}

\section{Latar Belakang}

Transaksi penawaran umum penjualan saham perdana atau yang disebut dengan IPO (Initial Public Offering) untuk pertama kalinya terjadi di pasar perdana (primary market) kemudian saham dapat diperjual belikan di bursa efek, yang disebut sebagai pasar sekunder (secondary market). Harga saham pada penawaran perdana ditentukan berdasarkan kesepakatan bersama antara perusahaan emiten dengan underwriter (penjamin emisi efek) yang ditunjuk oleh perusahaan emiten, sedangkan harga saham di pasar sekunder ditentukan oleh mekanisme pasar (berdasarkan permintaan dan penawaran). Underwriter dalam hal ini memperoleh informasi lebih baik mengenai permintaan saham-sham emiten, dibanding emiten itu sendiri. Oleh karena itu underwriter akan memanfaatkan informasi yng dimilikinya untuk memperoleh kesepakatan optimal dengan emiten, yaitu dengan memperkecil resiko keharusan membeli saham yang tidak laku terjual dengan harga murah. Sehingga emiten harus menerima harga yang murah bagi saham perdananya.

Salah satu syarat yang ditetapkan oleh BAPEPAM untuk perusahaan yang akan melakukan penawaran saham di pasar modal adalah dokumen prospektus. Dimana dokumen ini merupakan salah satu sumber informasi yang relevan untuk digunakan dalam menilai perusahaan yang akan go public. Prospektus berisi ten-

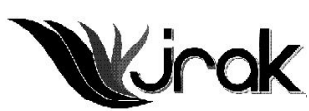

Jurnal Reviu Akuntansi dan Keuangan

ISSN: 2088-0685

Vol.1 No. 2, Oktober 2011 


\section{Fenomena Manajemen Laba...}

tang perusahaan penerbit sekuritas dan sebagian tentang laporan keuangan is ${ }^{-}$ suers selama 3 tahun sebelum IPO yang telah di audit oleh Kantor Akuntan Publik (KAP). Informasi yang menjadi perhatian penting dalam laporan keuangan dalah informasi mengenai laba. Menyadari ketergantungan calon investor dan underwriter terhadap informasi yang dimuat dalam prospektus, maka issuers terdorong untuk menyajikan informasi yang dapat memperlihatkan bahwa perusahaan memiliki kinerja yang baik.

Agar kinerja perusahaan terlihat bagus, manajemen berusaha untuk mengatur laba, yaitu dengan melakukan manajemen laba. Ada berbagai cara dalam manajemen laba, diantaranya pemilihan metode akuntansi atau kebijakan akrual, tetapi cara yang paling sering dilakukan adalah dengan kebijakan akrual (discretionary accrual), yaitu dengan mengendalikan transaksi akrual sehingga laba terlihat tinggi. Akan tetapi , transaksi tersebut tidak mempengaruhi aliran kas, misalnya waktu dari pengakuan pendapatan sehingga kebijakan akrual akan dapat mempengaruhi kualitas laba suatu perusahaan. Menurut Roshan dalam Astuti (2007:2) bahwa transaksi akrual terdiri atas transaksi non-discretionary accruals dan discretionary accruals, transaksi non-discretionary accruals misalnya biaya depresiasi, sedangkan transaksi discretionary accruals misalnya waktu dari pengakuan pendapatan. Sejumlah study menggunakan model kebijakan akrual untuk meneliti manipulasi dari akrual dalam mencapai tujuan earnings management (Dechow, 2002).

Gumanti (2001:166) menyatakan salah satu penyebab sulitnya penetapan harga penawaran karena tidak adanya informasi harga yang relevan. Hal ini disebabkan karena sebelum pelaksanaan penawaran perdana saham perusahaan belum diperdagangkan sehingga baik calon investor maupun issuers dan underwriter sama-sama kesulitan dalam menilai dan menentukan harga yang wajar. Menurut Hughes dalam Scoot (2000:306) bahwa informasi seperti net income digunakan untuk membantu menentukan nilai perusahaan oleh investor.

Sebagian besar penelitian mengenai manajemen laba melakukan pendekatan accruals. Dalam penelitian ini penulis juga menggunakan pendekatan accrual yang pada awalnya dikembangkan oleh De Angelo (1986). Model ini kemudian di modifikasi oleh Aharony, Lin dan Loeb (1993) dan Friedlan (1994). Menurut Gumanti (2001:172), pengukuran manajemen laba dengan menggunakan model Jones tidak memungkinkan digunakan di Indonesia karena keterbatasan data yaitu laporan keuangan yang terdapat dalam prospektus untuk perusahaan yang akan go public di Indonesia rata-rata terdiri dari 3 tahun sedangkan pengukuran manajemen laba dengan menggunakan pendekatan model Jones memerlukan pendekatan paling tidak 5 tahun.

Hal yang menarik dari penelitian mengenai manajemen laba dalam IPO adalah penelitian yang dapat membuktikan adanya kecenderungan issuers melakukan manajemen laba dalam IPO dan ada juga penelitian yang tidak dapat membuktikan kecenderungan issuers melakukan manajemen laba dalam IPO. Penelitian manajemen laba pada saat IPO di BEI pernah dilakukan oleh Gumanti (2001). Ia menemukan bahwa manajemen laba tidak terbukti secara kuat dilakukan pada 1 tahun sebelum go public melainkan pada periode 2 tahun sebelum go public. Setiawati (2002) menemukan adanya manajemen laba pada 1 tahun sebelum dan sesudah melakukan IPO pada perusahaan manufaktur. Dan penelitian yang dilakukan oleh Tiono (2004) menemukan adanya manajemen laba dengan menerapkan income-increasing discretionary accruals pada periode 2 tahun atau 1 tahun sebelum IPO tetapi pada periode 1 tahun setelah IPO tidak ada bukti yang kuat adanya manajemen laba dengan menerapkan income-decresing discretionary accruals.

Melihat masih kurang konsistennya hasil penelitian manajemen laba dalam IPO, maka masih diperlukan penelitian lanjutan untuk menguji fenomena manajemen laba dalam IPO. Oleh karena itu, pada penelitian ini penulis menggunakan model De Angelo \& Linda (1986) dengan pendekatan dasar accrual yang telah 


\section{Identifikasi Masalah}

1. Apakah perusahaan manufaktur melakukan manajemen laba dengan menerapkan Income-increasing discretionary accruals pada periode satu tahun sebelum IPO?

2. Apakah perusahaan manufaktur melakukan manajemen laba dengan menerapkan Income-decreasing discretionary accruals pada periode satu tahun dan dua tahun setelah IPO?

3. Apakah Return On Asset (ROA) perusahaan manufaktur yang terdaftar di BEI mengalami perubahaan per tahun yang signifikan di sekitar IPO?

4. Apakah ukuran perusahaan mempengaruhi kecenderungan go public untuk melakukan manajemen laba pada periode sebelum dan setelah IPO?

5. Apakah kelompok industri mempengaruhi kecenderungan perusahaan go public untuk melakukan manajemen laba periode sebelum dan setelah IPO?

\section{Kerangka Pemikiran \& Hipotesis}

Model penelitian yang digunakan oleh Friedlan (1994) untuk menjelaskan terjadinya manajemen laba dengan menerapkan kebijakan accrual pada periode sebelum IPO dan setelah IPO adalah discretionary accruals, perubahan laba bersih operasi, perubahaan total accruals adalah nol maka tidak ditemukan indikasi terjadi manajemen laba. Bila nilai discretionary accruals adalah positif mengindikasian telah terjadi manajemen laba dengan menerapkan kebijakan accrual yang dapat meningkatkan laba (income-increasing discretionary accruals). Bila nilai discretionary accruals negatif mengidentifikasikan telah terjadi manajemen laba dengan menerapkan kebijakan akuntansi accrual yang dapat menurunkan laba (incomedecreasing discretionary accruals). Bila perubahan laba bersih operasi positif menunjukna peningkatan laba bersih operasi dari periode sebelumnya. Perubahaan arus kas dari atau untuk operasi positif menunjukan meningkatnya arus kas dan bila negative menunjukan penurunan dari periode sebelumnya. Perubahan total accrual positif menunjukan adanya kenaikan nilai accrual dari periode sebelumnya dan bila negatif menunjukan penurunan nilai accrual.

Variabel-variabel penelitian yang digunakan oleh Aharony et al. dan Friedlan adalah sebagai berikut :

Aharony $\rightarrow$ Variabel: UAC, UNI, dan UCF

Friedlan $\rightarrow$ Variabel: DAC, Perubahan laba, Perubahan arus kas, Perubahan total accrual.

Berdasarkan penjelasan diatas maka dapat digambarkan skema sebagai berikut:

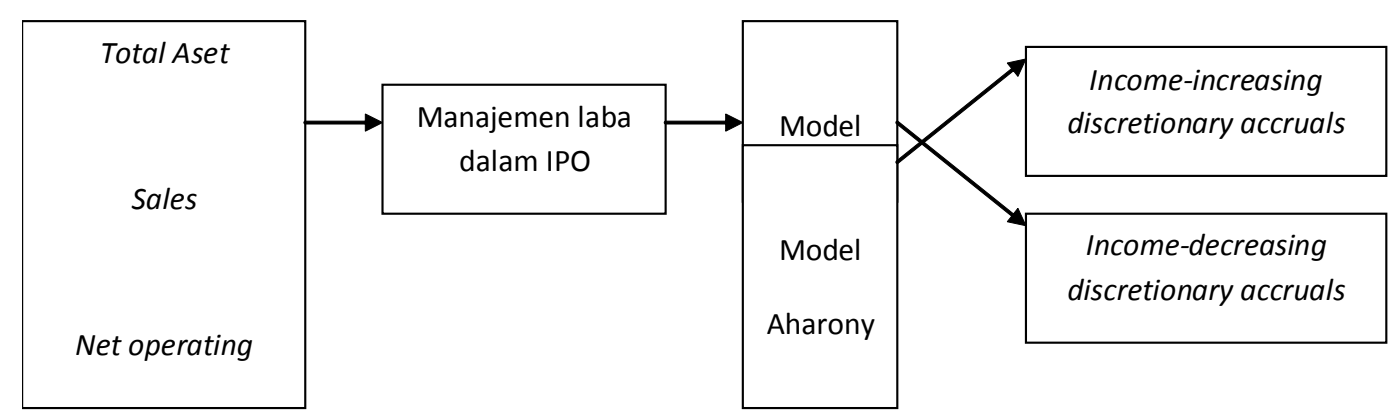

Gambar 1:

Kerangka Pemikiran Penelitian 


\section{Fenomena Manajemen Laba...}

Berdasarkan kerangka pemikiran diatas, hipotesis yang diuji dalam penelitian adalah sebagai berikut:

$\mathrm{H}_{\mathrm{a1}}$ : Issuers melakukan manajemen laba dengan menerapkan income-increasing discretionary accruals pada periode satu tahun sebelum IPO

$\mathrm{H}_{\mathrm{a} 2}$ : Issuers melakukan manajemen laba dengan menerapkan income-decreasing discretionary accruals pada periode satu

\section{METODE}

Obyek penelitian yang digunakan oleh peneliti pada penelitian ini adalah perusahaan manufaktur, yaitu PT Multistrada Arah Sarana yang melakukan penawaran saham perdana (IPO) di Bursa Efek Indonesia. Penelitian ini menggunakan model Jones yang bertujuan untuk mengendalikan pengaruh dari perubahaan kondisi ekonomi perusahaan terhadap nondiscretionary accruals. Adapun modelnya adalah:

TAt $\quad=$ DAt + NDAt

TAt $\quad=$ NIt - CFOt

NDAt $= \pm ?(1 /$ At-? $)+ \pm 2($ "REVt $/$ At-? $)+ \pm 3($ PPEt $/$ At-?)

DAt $\quad=$ TAt - NDAt

TAt $\quad=$ Total accruals

DAt $=$ Discretionary accruals

NIt $\quad=$ Net Income

CFOt $=$ Cash Flow from Operation

NDAt = Nondiscretionary accruals periode t yang diukur oleh total aktiva

"REVt = Revenue periode $\mathrm{t}$ dikurangi revenue periode $\mathrm{t}-$ ?

PPEt = Property plant dan equipment pada akhir tahun $\mathrm{t}$

At $-? \quad=$ Total aktiva pada akhir tahun $\mathrm{t}-$ ?

$\pm ?, \pm 2, \pm 3 \quad=$ Parameter perusahaan secara spesifik

Teknik pengumpulan data yang digunakan dalam penelitian ini adalah teknik observasi berupa data sekunder. Data perusahaan baik data keuangan maupun data informasi perusahaan dalam penelitian ini diperoleh dari prospectus dan laporan keuangan tahunan, yang didapatkan dari Pusat Referensi Pasar Modal (PRPM) BEI dan Pusat Data Pasar Modal (PDPM) IBII. Data-data keuangan yang diperlukan dalam penelitian ini adalah laba bersih, arus kas dari operasi, total aset, total pendapatan, total plant property and equipement. Sedangkan informasi perusahaan yang diperlukan adalah kode perusahaan, nama perusahaan. Tanggal berdirinya perusahaan, tanggal listing, harga penawaran, jumlah saham yang ditawarkan, bidang usaha perusahaan, dan kelompok industri. Data keuangan yang dibutuhkan dalam penelitian ini adalah data keuangan periode tiga tahun sebelum IPO (tahun 2002), dua tahun sebelum IPO (tahun 2003), satu tahun sebelum IPO (tahun 2004), pada tahun IPO (tahun 2005), satu tahun setelah IPO (tahun 2006), dan dua tahun setelah IPO (tahun 2007).

Gambar 2: Periode Waktu dalam Analisis Manajemen Laba di IPO

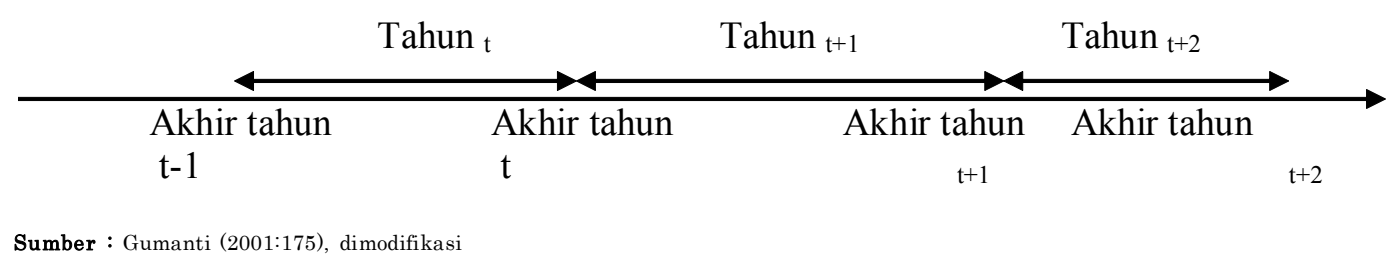


Tahapan analisis data dilakukan sebagai berikut:

1. Untuk melihat deskripsi data secara keseluruhan, maka dilakukan penghitungan mean, median, nilai minimum (nilai terkecil), nilai maksimum (nilai terbesar) serta standar deviasi dari tiap variable yang akan diuji (digunakan) dalam penelitian ini. Penghitungan ini dapat dilakukan dengan menggunakan Microsoft Excel.

2. Data keuangan, yaitu net income (laba bersih), cash flow from operation (arus kas dari operasi), total aktiva, total pendapatan, total plant property and equipement yang telah dikumpulkan dimasukan dalam tabel pengolahan data pada program Microsoft Excel. Dan kemudian menghitung nilai Total Accruals, Non Discretionary Accruals baru kemudian menghitung Discretionary Accruals. Penghitungan ini dilakukan dengan menggunakan program Microsoft Excel.

3. Batasan masalah pertama: apakah issuer melakukan manajemen laba menerapkan income-increasing discretionary accruals untuk menaikan tingkat laba yang dilaporkan pada periode satu tahun sebelum IPO?

(1) Buat gambar pada data Discretionary Accruals pada tahun 2002 hingga 2005. Pada tahap kali ini juga menggunakan program Microsoft Excel.

(2) Lakukan uji beda dua rata-rata untuk dua sampel yang berhubungan.

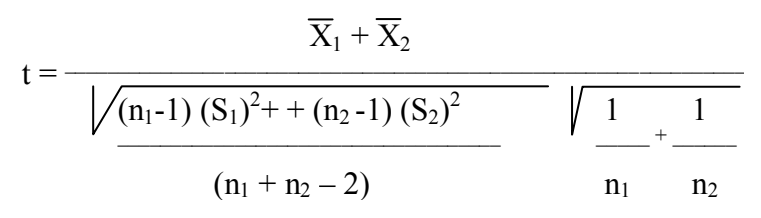

Dilakukan pengujian hipotesis, sebagai berikut :

$\mathrm{t}$ tabel $\pm=0.025$, df $(4+5-2)=\mathrm{t}$ hitung $\pm=0.025$, df $(7)=2.365$

Ho $\rightarrow \mathrm{x}_{1}=\mathrm{x}_{2}$ diterima jika $\mathrm{t}$ tabel $<\mathrm{t}$ hitung $<\mathrm{t}$ tabel.

$\mathrm{Ha} \rightarrow \mathrm{x}_{1}=\mathrm{x}_{2}$ ditolak jika $\mathrm{t}$ hitung $<\mathrm{t}$ tabel atau $\mathrm{t}$ hitung $>\mathrm{t}$ tabel.

4. Batasan masalah kedua: apakah issuer melakukan manajemen laba menerapkan income-decreasing discretionary accruals pada periode satu tahun dan dua tahun setelah IPO untuk membalikan kebijakan akrual yang dilakukan pada periode sebelumnya?

a. Buat gambar pada data Discretionary Accruals pada tahun 2002 hingga 2007. Pada tahap kali ini juga menggunakan program Microsoft Excel.

b. Lakukan uji beda dua rata-rata untuk dua sampel yang berhubungan.

$$
\mathrm{t}=\frac{\overline{\mathrm{X}}_{1}+\overline{\mathrm{X}}_{2}}{\frac{\sqrt{\frac{\left(\mathrm{n}_{1}-1\right)\left(\mathrm{S}_{1}\right)^{2}++\left(\mathrm{n}_{2}-1\right)\left(\mathrm{S}_{2}\right)^{2}}{\left(\mathrm{n}_{1}+\mathrm{n}_{2}-2\right)}}}{\frac{1}{\mathrm{n}_{1}}+\frac{1}{\mathrm{n}_{2}}}}
$$

Dilakukan pengujian hipotesis, sebagai berikut:

$\mathrm{t}$ tabel $\pm=0.025$, df $(4+5-2)=\mathrm{t}$ hitung $\pm=0.025$, df $(7)=2.365$

Ho $\rightarrow \mathrm{x}_{1}=\mathrm{x}_{2}$ diterima jika $\mathrm{t}$ tabel $<\mathrm{t}$ hitung $<\mathrm{t}$ tabel.

$\mathrm{Ha} \rightarrow \mathrm{x}_{1}=\mathrm{x}_{2}$ ditolak jika $\mathrm{t}$ hitung $<\mathrm{t}$ tabel atau $\mathrm{t}$ hitung $>\mathrm{t}$ tabel.

\section{HASIL DAN PEMBAHASAN}

\section{Deskripsi Data}

Penelitian ini menguji manajemen laba sebelum dan sesudah penawaran saham perdana. Data perusahaan yang digunakan adalah data PT Multistrada Arah Sarana, yang bergerak dalam industri manufaktur yang melakukan penawaran saham perdana (IPO) yang terdaftar di Bursa Efek Indonesia. 


\section{Fenomena Manajemen Laba...}

\section{6}

Tabel 4.1
Tabel Frekuensi 1

\begin{tabular}{|c|c|c|c|c|c|c|c|c|}
\hline & dac & $\begin{array}{l}\text { tac/ } \\
\text { tat-1 }\end{array}$ & $\begin{array}{l}\text { (drev- } \\
\text { drec)/ } \\
\text { tat-1 }\end{array}$ & $\begin{array}{l}\text { ppe/ } \\
\text { tat-1 }\end{array}$ & ni & cfo & tac & tat-1 \\
\hline mean & $-0,48$ & 0,82 & 0,15 & 1,152 & 394.256 .307 .546 & 8.793.972.216 & 385.462 .335 .331 & 759.335 .328 .802 \\
\hline \multirow[t]{2}{*}{ median } & $-1,12$ & 0,07 & 0,14 & 1,058 & 114.863 .281 .611 & $\begin{array}{r}367.240 .986 \\
-\end{array}$ & 82.162 .288 .307 & 642.293 .233 .413 \\
\hline & & & & & & 43.769.781.20 & & \\
\hline \multirow[t]{2}{*}{ minimum } & $-1,21$ & $-0,2$ & 0,07 & 0,854 & -79.672 .428 .809 & 7 & -86.142 .546 .577 & 281.271.670.149 \\
\hline & & & & & 2.015.564.935.69 & 78.656 .353 .11 & 2.022.316.627.29 & 1.433 .688 .362 .87 \\
\hline maximum & 2,68 & 4,27 & 0,21 & 1,628 & 5 & 6 & 5 & 1 \\
\hline stdeviatio & 1,55 & & & & & 40.816 .425 .55 & & \\
\hline $\mathrm{n}$ & 1 & 1,71 & 0,06 & 0,314 & 799.835.794.038 & 3 & 806.447 .266 .055 & 434.445 .688 .169 \\
\hline
\end{tabular}

Sumber: hasil olah data

\section{Keterangan:}

dac

tac/tat $-1=$ total accruals periode $\mathrm{t}$ dibagi total assets periode $\mathrm{t}-1$

drev $\quad=$ perubahan penghasilan periode $t$ dan penghasilan periode $t-1$

drec $\quad=$ perubahan piutang usaha periode $t$ dan piutang usaha periode $\mathrm{t}-1$

$\left(\mathrm{drev}^{-} \mathrm{drec}\right) /$ tat $^{-1}=$ perubahan penghasilan dikurangi perubahan piutang usaha dibagi dengan total assets periode $\mathrm{t}-1$

ppe/tat $-1=$ plant property and equipement periode $\mathrm{t}$ dibagi total assets periode $\mathrm{t}-1$

ni $\quad=$ net income

cfo $\quad=$ arus kas dari aktivitas operasi

tac $\quad=$ total akrual, yaitu dari net income dikurangi arus kas dari aktivitas operasi

tat $-1=$ total aset periode $\mathrm{t}-1$

Dari tabel diatas dapat diketahui bahwa net income (laba bersih) mempunyai rata-rata sebesar 394.256.307.546, nilai tengah (median) sebesar 114.863.281.611, dan berkisar diantara -79.672.428.809 hingga 2.015.564.935.695. CFO (arus kas dari aktivitas operasi) mempunyai rata-rata sebesar 8.793.972.216, nilai tengah sebesar 8.793.972.216, serta berada diantara -43.769.781.207 hingga 78.656.353.116. Sedangkan total accruals mempunyai nilai rata-rata sebesar 385.462.335.331, nilai tengah sebesar 82.162.288.307, nilai terkecil sebesar 86.142.546.577 dan nilai terbesar sebesar 2.022.316.627.295.

Disisi lain, tabel diatas juga memberitahu kita bahwa total assets periode t1 mempunyai mean sebesar 759.335.328.802, median sebesar 82.162.288.307, nilai minimum sebesar -86.142.546.577 dan nilai maximum sebesar 2.022.316.627.295.

\section{Hasil Pengujian Hipotesis 1}

Pengujian ini dilakukan untuk menguji Hipotesis $\mathrm{H}_{\mathrm{a} 1}$ yang menyatakan bahwa issuers melakukan manajemen laba dengan menerapkan income-increasing discretionary accruals pada periode satu tahun sebelum IPO.

Gambar 3:

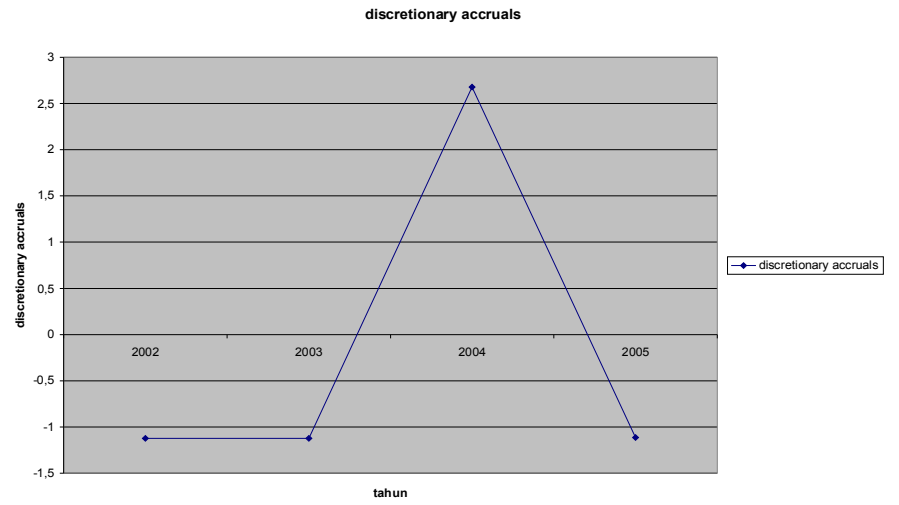


Dari gambar 3 dapat diketahui bahwa secara kasat mata, discretionary accruals meningkat dari tahun 2002 hingga tahun 2004 dan menurun dari tahun 2004 ke tahun 2005. Peningkatan discretionary accruals terjadi secara menonjol dari tahun 2003 ke tahun 2004. Hal ini menimbulkan kecurigaan adanya indikasi manajemen laba di tahun 2004, yang merupakan periode satu tahun sebelum penawaran saham perdana.

Selanjutnya dilakukan pengujian untuk menguji apakah memang benar terdapat manajemen laba di tahun 2004. Pengujian dilakukan dengan dua jenis sampel untuk menentukan signifikansi perbedaan rata-rata discreationary accruals tahun 2002 hingga 2003 dan rata-rata discretionary accruals tahun 2002 hingga 2004 pada $\pm=0.05$.

$$
\begin{aligned}
& \mathrm{X}_{1}=-1,36356 \quad \mathrm{X}_{2}=-0,11679 \\
& \mathrm{~S}_{1}=0,029233 \quad \mathrm{~S}_{2}=2,159581 \\
& t=\frac{\bar{X}_{1}+\bar{X}_{2}}{\sqrt{\frac{\left(n_{1}-1\right)\left(S_{1}\right)^{2}+\left(n_{2}-1\right)\left(S_{2}\right)^{2}}{\left(n_{1}+n_{2}-2\right)}} \sqrt{\frac{1}{n_{1}}+\frac{1}{n_{2}}}} \\
& t=\frac{-1,36356+0,11679}{\sqrt{\frac{(1)(0,029233)^{2}+(2)(2,159581)^{2}}{(2+3-2)}} \sqrt{\frac{1}{2}+\frac{1}{3}}} \\
& t=-0,774
\end{aligned}
$$

t-tabel dengan $\pm=0.025$ dan df (2+3-2) adalah 3.182

Ho à $\mathrm{X}_{1}=\mathrm{X}_{2}$ diterima jika minus $\mathrm{t}$-tabel $<\mathrm{t}$ hitung $<\mathrm{t}$ tabel.

$\mathrm{Ha}$ à $\mathrm{X}_{1}=\mathrm{X}_{2}$ ditolak jika $\mathrm{t}$ hitung $<\mathrm{t}$ tabel atau $\mathrm{t}$ hitung $>\mathrm{t}$ tabel.

Karena -3.182 ( $\mathrm{t}$ tabel $)<-0.774$ (t hitung) $<$ dari 3.182 (t tabel), maka Ho diterima atau Ha ditolak. Hal ini berarti tidak ada perbedaan yang signifikan antara rata-rata discretionary accruals tahun 2002 hingga tahun 2003 dan ratarata discretionary accruals tahun 2002 hingga tahun 2004 dengan tingkat kepercayaan $95 \%( \pm=0.05)$.

Berdasarkan gambar 3 terjadi peningkatan discretionary accruals yang sangat drastis dari tahun 2003 ke 2004 atau tepatnya satu tahun sebelum perusahaan melakukan IPO. Setelah dilakukan uji beda dua rata-rata, maka dapat diketahui bahwa hipotesis null pertama diterima atau hipotesis alternatif pertama ditolak, sehingga dapat diindikasikan bahwa issuers tidak melakukan manajemen laba dengan tidak menerapkan income-increasing discretionary accruals pada periode satu tahun sebelum IPO.

Dengan berbagai manfaat yang dapat diperoleh melalui penawaran saham perdana (tentu saja setelah melalui penganalisaan yang mendalam bahwa manfaat yang akan diterima jauh lebih besar daripada kos yang akan dikeluarkan dalam penawaran saham perdana, maka manajemen cenderung melakukan manajemen laba sebelum penawaran saham perdana, tetapi dalam hal ini, PT Multistrada Arah Sarana tidak melakukan manajemen laba.

PT Multisrada Arah Sarana terbukti tidak melakukan manajemen laba, karena manajemen yakin bahwa laporan keuangan akan memberikan informasi keuangan yang sebenarnya tentang kondisi keuangan perusahaan. Berdasarkan Ikatan Akuntansi (2004), tujuan laporan keuangan adalah menyediakan informasi yang menyangkut posisi keuangan, kinerja serta perubahaan posisi keuangan suatu perusahaan yang bermanfaat bagi sejumlah besar pemakai dalam pengambilan keputusan ekonomi. Laporan keuangan juga menunjukan apa yang telah dilakukan manajemen (stewardship), atau pertanggungjawaban manajemen atas sumber daya yang dipercayakan kepadanya. 


\section{Fenomena \\ Manajemen \\ Laba...}

158
Hasil penelitian ini sesuai dengan penelitian yang dilakukan oleh Aharony, Lin \& Loeb (1993) dan penelitian lainnya yang mana terdapat manajemen laba pada satu tahun sebelum IPO.

\section{Hasil pengujian hipotesis 2}

Hipotesis 2 menguji bahwa issuers melakukan manajemen laba dengan menerapkan income-decreasing discretionary accruals pada periode satu tahun dan dua tahun setelah IPO.

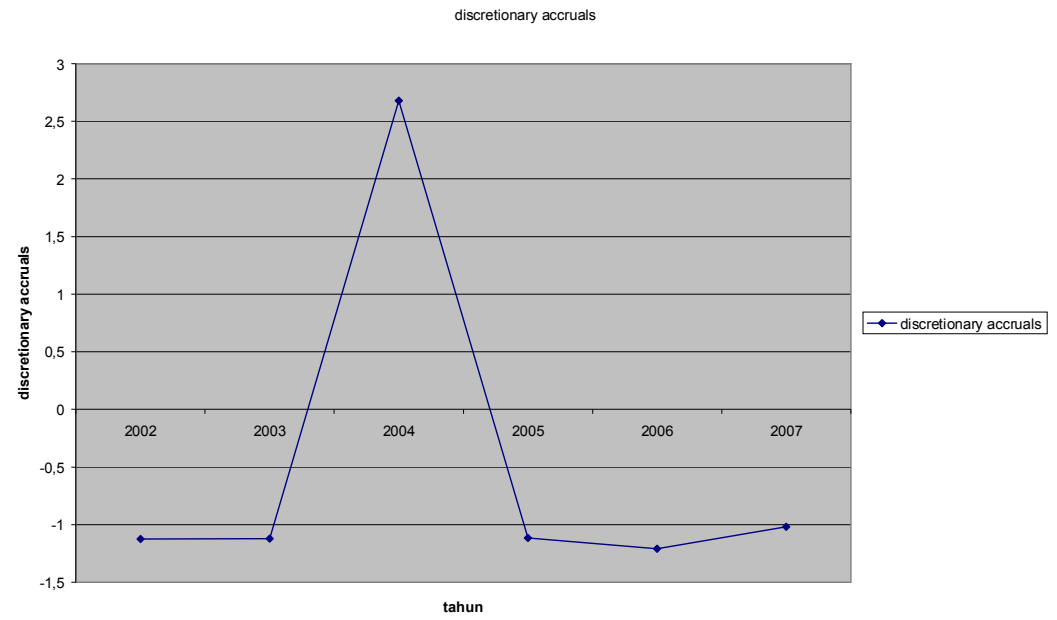

Dari gambar 4 dapat diketahui bahwa setelah melakukan IPO atau penawaran saham perdana, discretionary accruals menurun drastis. Hal ini terlihat pada penurunan discretionary accruals tahun 2004 ke 2005 dan berlanjut ke tahun 2006. Tetapi kemudian meningkat lagi di tahun 2007.

Pengujian kemudian dilanjutkan dengan uji beda dua rata-rata pada periode satu dan dua tahun setelah IPO.

- Uji beda dua rata-rata untuk periode 1 tahun setelah IPO

$$
\begin{array}{ll}
\mathrm{X}_{1}=-0.11679 & \mathrm{X}_{2}=-0.43625 \\
\mathrm{~S}_{1}=2.159581 & \mathrm{~S}_{2}=1.875482
\end{array}
$$

$$
t=\frac{\bar{X}_{1}+\bar{X}_{2}}{\sqrt{\frac{\left(n_{1}-1\right)\left(S_{1}\right)^{2}+\left(n_{2}-1\right)\left(S_{2}\right)^{2}}{\left(n_{1}+n_{2}-2\right)}} \sqrt{\frac{1}{n_{1}}+\frac{1}{n_{2}}}}
$$

$$
t=\frac{-0.11679+0.43625}{\sqrt{\frac{(2)(2,159581)^{2}+(3)(1,875482)^{2}}{(3+4-2)}} \sqrt{\frac{1}{3}+\frac{1}{4}}}
$$

$t=-0,1052$

$\mathrm{t}$-tabel $\pm=0.025$, df $(3+4-2)=\mathrm{t}$-hitung $\pm=0.025$, df $(5)=2.571$

Ho à $\mathrm{X}_{1}=\mathrm{X}_{2}$ diterima jika minus $\mathrm{t}$-tabel $<\mathrm{t}$ hitung $<\mathrm{t}$ tabel.

Ha à $\mathrm{X}_{1}=\mathrm{X}_{2}$ ditolak jika t-hitung $<\mathrm{t}$-tabel atau t-hitung $>\mathrm{t}$-tabel.

Karena 2.571 ( $\mathrm{t}$ tabel $)<0.1052$ ( $\mathrm{t}$ hitung) $<2.571$ ( t tabel), maka Ho diterima atau Ha ditolak. Hal ini berarti ada tidak ada perbedaan yang signifikan antara rata-rata discretionary accruals tahun 2002 hingga tahun 2004 dan rata-rata discretionary accruals tahun 2002 hingga tahun 2005 dengan tingkat kepercayaan $95 \%( \pm=0.05)$.

Hal ini berarti rata-rata discretionary accruals tahun 2002 hingga tahun 2004 dan rata-rata discretionary accruals tahun 2002 hingga tahun 2005 tidak 
dapat dibandingkan, sehingga dapat disimpulkan bahwa hipotesis null kedua diterima atau hipotesis alternatif kedua ditolak. Dengan kata lain, dapat dikatakan bahwa issuers tidak melakukan manajemen laba dengan tidak menerap-

kan income-decreasing discretionary accruals pada periode satu tahun setelah IPO.

- Uji beda dua rata-rata untuk periode 2 tahun setelah IPO

$$
\begin{array}{ll}
\mathrm{X}_{1}=-0.43625 & \mathrm{X}_{2}=-0.65109 \\
\mathrm{~S}_{1}=1.875482 & \mathrm{~S}_{2}=1.693769
\end{array}
$$

$$
t=\frac{\bar{X}_{1}+\bar{X}_{2}}{\sqrt{\frac{\left(n_{1}-1\right)\left(S_{1}\right)^{2}+\left(n_{2}-1\right)\left(S_{2}\right)^{2}}{\left(n_{1}+n_{2}-2\right)}} \sqrt{\frac{1}{n_{1}}+\frac{1}{n_{2}}}}
$$

$$
t=\frac{-0,43625+0,65109}{\sqrt{\frac{(4)(1,875482)^{2}+(5)(1,693769)^{2}}{(4+5-2)}} \sqrt{\frac{1}{4}+\frac{1}{5}}}
$$

$t=-0,1805$

t-tabel $\pm=0.025$, df $(4+5-2)=$ t-hitung $\pm=0.025$, df $(7)=2.365$

Ho $\rightarrow \mathrm{X}_{1}=\mathrm{X}_{2}$ diterima jika minus $\mathrm{t}$-tabel $<\mathrm{t}$ hitung $<\mathrm{t}$-tabel.

$\mathrm{Ha} \rightarrow \mathrm{X}_{1}=\mathrm{X}_{2}$ ditolak jika t-hitung $<\mathrm{t}$-tabel atau t-hitung $>\mathrm{t}$-tabel.

Karena $2.365(\mathrm{t}$ tabel $)<0.1805$ ( $\mathrm{t}$ hitung $)<2.365$ ( $\mathrm{t}$ tabel), maka Ho diterima atau Ha ditolak. Hal ini berarti ada tidak ada perbedaan yang signifikan antara rata-rata discretionary accruals tahun 2002 hingga tahun 2005 dan rata-rata discretionary accruals tahun 2002 hingga tahun 2006 dengan tingkat kepercayaan $95 \%( \pm=0.05)$.

Hal ini berarti rata-rata discretionary accruals tahun 2002 hingga tahun 2005 dan rata-rata discretionary accruals tahun 2002 hingga tahun 2006 tidak dapat dibandingkan, sehingga dapat disimpulkan bahwa hipotesis null kedua diterima atau hipotesis alternatif kedua ditolak. Atau dapat dikatakan bahwa issuers tidak melakukan manajemen laba dengan tidak menerapkan incomedecreasing discretionary accruals pada periode dua tahun setelah IPO.

Terjadi penurunan discretionary accruals yang sangat drastis dari tahun 2004 ke 2005 atau tepatnya satu tahun setelah perusahaan melakukan IPO. Setelah dilakukan uji beda dua rata-rata, maka dapat diketahui bahwa hipotesis null kedua diterima atau hipotesis alternatif kedua ditolak, sehingga dapat diindikasikan bahwa issuers tidak melakukan manajemen laba dengan tidak menerapkan income-decreasing discretionary accruals pada periode satu tahun dan dua tahun setelah IPO.

Dengan adanya hasil uji hipotesis kedua, maka dapat diyakinkan bahwa PT Multisrada Arah Sarana terbukti tidak melakukan manajemen laba baik sebelum penawaran umum saham perdana (sebelum IPO) maupun setelah penawaran umum saham perdana (sesudah IPO), karena manajemen yakin bahwa laporan keuangan akan memberikan informasi keuangan yang sebenarnya tentang kondisi keuangan perusahaan.

Manajemen perusahaan yakin bahwa informasi keuangan, terutama laba, yang tertera di laporan keuangan menjadi daya tarik tersendiri oleh investor untuk menanamkan sahamnya di PT Multisrada Arah Sarana. Manajemen tidak perlu melakukan manajemen laba, karena informasi keuangan di laporan keuangan perusahaan sudah menunjukkan posisi keuangan yang bagus tanpa harus melakukan manajemen laba. Manajemen mempunyai optimisme yang besar bahwa 


\section{Fenomena Manajemen Laba...}

160

informasi keuangan perusahaan dapat menarik perhatian para investor pada penawaran saham perdana untuk menanamkan dananya dengan membeli saham perusahaan.

Hasil penelitian ini sesuai dengan penelitian yang dilakukan oleh Aharony et al. (1993) dan penelitian lainnya yang mana terdapat manajemen laba pada satu tahun sebelum IPO.

\section{SIMPULAN}

Berdasarkan kajian dalam penelitian, baik $\mathrm{H} 1$ maupun $\mathrm{H} 2$ tidak dapat diterima. Hal ini berarti issuers tidak melakukan manajemen laba dengan tidak menerapkan income-increasing discretionary accruals pada periode satu tahun sebelum IPO. Selain itu, issuers juga tidak melakukan manajemen laba dengan menerapkan tidak menerapkan income-decreasing discretionary accruals pada periode satu tahun dan dua tahun setelah IPO.

\section{DAFTAR PUSTAKA}

Aharony, Joseph, Chan-Jane Lin, dan Martin P. Loeb, 1993. "Initial Public Offerings, Accounting Choices, and Earnings Management". Contemporary Accounting Research. Vol 10. No 1. hal.61-68

Astuti, DSP. 2007. "Kemampuan Laba dan Arus Kas dalam Memprediksi Laba dan Arus Kas Perusahaan Go Publik di Pasar Modal". Tesis S2 Program Pasca Sarjana UGM, Yogyakarta

Bitner, L.N., and R. Dolan. 1996. :Assessing the Relationship Between Income Smoothing and the Value of The Firm”. Quarterly Journal of business and Economics. Winter : p.16-35

Chan. 2001. "Earnings Quality and Stock Returns. National Berueau of Economic Reseach". Working Paper

DeAngelo and Linda, E. 1986. "Accounting Numbers as Market Valuation Subtitutes: A Study of Management Buyouts of Public Stockholders". The Accounting Review. Vol 59. hal.400-420

Dechow, P., 1995. "Accounting Earnings and Cash Flows as Measures of Firm Performance: The Role of Accounting Accruals". Journal of Accounting and Economics 18: p.3-42.

Friedlan, JM. 1994. "Accounting Choices of issuers of Initial Public Offerings". Contemporary Accounting Research.Vol 11. Summer 1994. hal.1-31

Jensen, M.C., and W. H. Meckling. 1976. "Theory of The Firm: Manajerial Behaviour, Agency Cost, and Ownership Structure”. Journal of Financial and Economics, 3, 305-360

Jones, JJ. 1989. "Earnings Management during Import Relief Investigation”. Journal of Accounting Research. Vol 29. No 2. hal 193-228

Gumanti. 2001. Paradigma Manajemen Laba di Indonesia. Jakarta.2001

Scoot, W.R. 2000. "Nature and Amount of Information Reflected in Cash Flows and Accruals". The Accounting Review, 64 (October), p. 624-952

Setiawati, Lilis. 2002. "Manajemen Laba dan IPO di Bursa Efek Jakarta". Prosiding Simposium Nasional Akuntansi V. hal.112-115

Tiono. 2004. "Manajemen Laba dalam Initial Public Offering (IPO) di Bursa Efek Jakarta". Prosiding Simposium Nasional Akuntansi VII. hal 1072-1089

Widyaningsih, AU. 2001. "Analisis Faktor-faktor yang Berpengaruh terhadap Earnings Management pada Perusahaan Go Public di Indonesia”. Jurnal Akuntansi dan Keuangan. Vol 3. No 2. hal.89-101

Watts R. and J.L. Zimmerman. 1986. Positive Accounting Theory. New York: PrenticeHall 